\title{
Penguatan Kapasitas Tata Kelola Keuangan dan Komunikasi pada Pelaksanaan Program Badan Usaha Milik Desa di Desa Gendro Pasuruan
}

\section{Strengthening Financial Governance and Communication Capacity in The Implementation of Village-Owned Business Agency Programs in Gendro Village Pasuruan}

Rachmat Kriyantono $^{1 *}$, Yun Fitrahyati Laturrakhmi ${ }^{1}$, Sinta Swastikawara ${ }^{1}$, Dessanti Putri Sekti $\operatorname{Ari}^{2}$

${ }^{1}$ Jurusan Ilmu Komunikasi Fakultas Ilmu Sosial dan Ilmu Politik Universitas Brawijaya, Jl. Veteran Malang, Indonesia

${ }^{2}$ Fakultas Ilmu Administrasi Universitas Brawijaya, Jl. MT. Haryono 163, Malang, Indonesia

\begin{tabular}{|c|c|}
\hline Info Artikel & ABSTRAK \\
\hline $\begin{array}{l}\text { Diterima } 06 \text { Oktober } 2020 \\
\text { Ditelaah } 17 \text { Oktober } 2020 \\
\text { Disetujui } 13 \text { Nopember } 2020 \\
\text { Tersedia daring } 31 \text { Desember } \\
2020 \\
\text { *Penulis untuk korespondensi } \\
\text { rachmat_kr@ub.ac.id }\end{array}$ & $\begin{array}{l}\text { Artikel ini mendeskripsikan program pengabdian masyarakat untuk memberikan } \\
\text { penguatan kapasitas organisasi sehingga program Badan Usaha Milik Desa (BUMDES) } \\
\text { dapat berjalan efektif. BUMDES, sebagai program pemerintah untuk membangun desa, } \\
\text { menuntut kemampuan manajemen dari pelaksana program, baik pengurus BUMDES } \\
\text { maupun pemerintah desa. Kemampuan manajemen ini berkaitan transparansi dalam } \\
\text { pengelolaan anggaran dan manajemen komunikasi yang akhirnya menjadi salah satu } \\
\text { parameter yang turut menentukan tinggi rendahnya kepercayaan masyarakat terhadap } \\
\text { pengelolaan BUMDES. Tim Pengabdian Masyarakat bertujuan memberikan penguatan } \\
\text { kapasitas tata kelola keuangan dan komunikasi pada pengelolaan BUMDES di Desa }\end{array}$ \\
\hline $\begin{array}{l}\text { Kata Kunci: } \\
\text { BUMDES, } \\
\text { Desa Gendro, } \\
\text { Manajemen Komunikasi, } \\
\text { Transparansi Keuangan }\end{array}$ & $\begin{array}{l}\text { Gendro Kabupaten Pasuruan. Kegiatan dilakukan dengan metode workshop dan } \\
\text { pendampingan kepada pengelola BUMDES. Kegiatan ini diikuti semua pengelola } \\
\text { BUMDES dan aparat pemerintah desa. Kegiatan ini dilakukan sejak Juni hingga } \\
\text { September 2020. Kegiatan ini menemukan bahwa kapasitas tata kelola keuangan dan } \\
\text { komunikasi terkendala oleh kurangnya dukungan dari pemerintah desa, kendala } \\
\text { komunikasi antara pengelola BUMDES dan kepala desa, pengelola belum fokus secara } \\
\text { optimal, dan masih rendahnya kerjasama antar pengelola. Dari pre-test dan post-test } \\
\text { dengan uji Wilcoxon, ditemukan bahwa kegiatan ini mampu memberikan pemahaman } \\
\text { dan kemampuan aplikasi tentang pengelolaan laporan keuangan yang transparan dan } \\
\text { manajemen komunikasi yang efektif dengan pemerintah desa. Diharapkan, kapasitas ini } \\
\text { menjadikan BUMDES menjadi mandiri dan mampu berinovasi mengembangkan potensi } \\
\text { desa menjadi sumber usaha Desa Gendro. }\end{array}$ \\
\hline
\end{tabular}

Keywords:

BUMDES,

Financial transparency,

Communication Management,

Gendro Village

\section{ABSTRACT}

This article describes community service programs to provide organizational capacity strengthening to increase the Village-Owned Enterprises (BUMDES) program's effectiveness. BUMDES demands program implementers' management capabilities as a government program to develop villages, both BUMDES administrators and village governments. This management capability is related to transparency in budget management and communication management, which ultimately becomes one of the parameters that determine the level of public trust in the management of BUMDES. The Community Service Team aims to strengthen the capacity of financial governance and communication in the management of BUMDES in Gendro Village, Pasuruan Regency. Activities were carried out through workshops and assistance to BUMDES managers. This activity was attended by all BUMDES managers and village government officials. This activity was carried out from June to September 2020. This activity found that the capacity of financial and communication governance was constrained by a lack of support from the village government, communication problems between BUMDES managers and village heads, managers had not focused optimally, and low cooperation 
between managers. This activity was able to provide understanding and application capabilities regarding the management of transparent financial reports and effective communication management with the village government. It is hoped that this capacity will make BUMDES independent and able to innovate in developing village potentials to become a source of business for Gendro Village.

ISSN 2685-0354 (Media Online). Diterbitkan oleh Universitas Prof. Dr. Hazairin, SH. Ini merupakan jurnal bebas akses di bawah lisensi Creative Commons Atribution 4.0 International (https://creativecommons.org/licenses/by/4.0

\section{PENDAHULUAN}

Upaya pemerintah untuk membangun desa telah dilakukan sejak tahun 2015 yaitu berupa penganggaran dana desa. Dana tersebut ditujukan untuk membangun pedesaan sehingga dapat memberikan keuntungan ekonomi bagi masyarakat serta kemajuan desa tersebut (Kurnia, 2019). Untuk tahun 2019, Menteri Desa, Pembangunan Daerah Tertinggal, dan Transmigrasi menyarankan penggunaan dana desa lebih memfokuskan pada pemberdayaan ekonomi dan pemberdayaan masyarakat desa, dan tidak mengarahkan pada pembangunan infrastruktur (Tempo, 2019). Meskipun penyerapan dana desa terus meningkat setiap tahun, namun kasus penyelewengan dana desa di tingkat desa masih dijumpai walaupun hanya sebesar $0,01 \%$ (Kurnia, 2019).

Beberapa studi sebelumnya menunjukkan bahwa korupsi di tingkat desa dapat terjadi karena kurangnya pengawasan dan keterbukaan dalam penyelenggaraan pemerintahan desa (Rahman, 2011). Situasi ini terkait dengan masih tingginya indeks persepsi korupsi Indonesia, yakni ranking 85 dari 185 negara (Mashabi, 2020). Ditambah lagi, rendahnya kualitas sumber daya manusia (SDM) aparatur pemerintah desa (Bunga et al., 2018). Pada level pemerintahan desa, kecenderungan perilaku koruptif dapat terjadi setidaknya karena dua faktor, sebagaimana hasil penelitian Herdiana (2019). Pertama, faktor regulasi yang menempatkan kepala desa sebagai pemimpin sentral di tingkat desa dan tidak diimbangi oleh lembaga tingkat desa yang menjadi penyeimbang dan kontrol terhadap kepala desa. Kedua, faktor tidak adanya mekanisme yang jelas bagaimana masyarakat melakukan pemantauan terhadap kinerja kepada desa.

Sejalan dengan beberapa temuan tersebut, beberapa literatur menegaskan bahwa ketersediaan informasi berhubungan secara signifikan dengan perilaku korupsi. Dalam hal ini, adanya arus informasi antara pemerintah dan masyarakat menurunkan potensi terjadinya korupsi (Charoensukmongkol \& Moqbel, 2014; Kriyantono et al., 2017). Dalam konteks Indonesia, beberapa penelitian terdahulu juga menunjukkan bahwa keterbukaan informasi public (KIP) berdampak pada terbangunnya tata pemerintahan yang baik (good governance) sebagaimana ditemukan Retnowati (2012) maupun Febriananingsih (2012). Jatiningrum et al. (2020) juga menyebut bahwa cara untuk menghadapi skandal adalah dengan memperbaiki laporan keuangan melalui perbaikan tata kelola organisasinya. Ditambah lagi, transparansi laporan keuangan masih menjadi tuntutan masyarakat, bukan hanya di Indonesia (Batubara, 2017), tapi, juga terjadi di Amerika Serikat (Hawes et al., 2015). Transparansi juga menjadi faktor membangun relasi (Estrada \& Bastida, 2020), dalam hal ini relasi antara pengelola dan masyarakat desa.

Lebih lanjut, berdasarkan Undang-undang Nomor 14 Tahun 2008 tentang Keterbukaan Informasi Publik, disebutkan bahwa fungsi penyediaan informasi publik menjadi syarat penting pelaksanaan demokrasi. Dalam konteks lembaga pemerintah, misalnya, tata kelola komunikasi sebagai bagian dari fungsi pelayanan publik dan tata kelola komunikasi ini menjadi tugas bagian Humas (Kriyantono, 2015, 2019a, 2019b, 2020a). Dalam level desa, mengacu pada Kriyantono (2016), ketiadaan humas pemerintah menuntut fungsi ini dapat dijalankan oleh seluruh aparatur pemerintahan desa, karena setiap individu adalah Humas bagi lembaga. Meskipun demikian, tidak dapat diabaikan bahwa kualitas SDM yang ada di dalam pemerintahan desa turut menentukan bagaimana fungsi keterbukaan ini akan dilaksanakan. Keterbukaan keuangan dan komunikasi menjadi sangat penting karena Program Badan Usaha Milik Desa (BUMDES) sebagai program publik, mengacu pada Pina et al. (2010) dan Lawal et al. (2020), berkewajiban memberikan transparansi keuangan. BUMDES juga menuntut pengelolaan secara profesional sehingga dapat mengangkat status desa dari desa tertinggal menjadi desa maju (Anwar, 2020).

Dari observasi pendahuluan di Desa Gendro pada Juni 2020, sebagai upaya analisis situasi, Tim Pengabdian Masyarakat menemukan bahwa kapasitas manajemen ini dalam pengelolaan BUMDES menjadi permasalahan yang kerap terjadi. Di BUMDES Podo Makmur, Desa Gendro, Kecamatan Tutur, Kabupaten Pasuruan, Jawa Timur, Tim menemukan bahwa sejak didirikan di tahun 2018 lalu, pengelolaan BUMDES belum dilakukan secara optimal, yakni cenderung stagnan. Observasi dan wawancara awal dengan beberapa pengurus, tim menemukan bahwa meskipun pelaporan pengelolaan anggaran telah dilakukan, namun penyediaan informasi secara berkala kepada masyarakat secara langsung belum dilakukan. Komunikasi antar pengelola juga sangat jarang dilakukan. Komunikasi yang kurang 
efektif ini mengakibatkan beban kerja tidak terdistribusi secara merata antar pengelola dan transparansi keuangan belum terjadi.

Permasalahan lainnya yang juga muncul adalah tidak adanya komunikasi yang rutin dan bersifat koordinatif antara pengurus BUMDES dengan pendamping BUMDES dan pemerintah desa. Hasil observasi dan wawancara dengan pengurus, tim menemukan bahwa komunikasi antara pengurus BUMDES dengan pemerintah desa kurang efektif, yakni ditandai adanya rasa saling tidak percaya. Hal ini sangat berdampak pada tidak produktifnya pengelolaan BUMDES di desa ini. Masalah lain yang juga muncul adalah pengelola BUMDES dan pendamping BUMDES memiliki perbedaan pemahaman tentang aturan dasar BUMDES dan bagaimana penerapannya. Perbedaan ini pun menjadi gap koordinasi dan kerjasama.

Hasil observasi sebagai analisis situasi ini menegaskan pentingnya penguatan kapasitas bukan hanya bagi pengelola BUMDES tetapi juga bagi pendamping desa berkaitan dengan pengetahuan dasar tentang dasar hukum dan implementasinya pada program BUMDES di tingkat desa. Pada dasarnya, temuan ini sejalan dengan hasil penelitian Kadir dan Moonti (2018) yang menemukan bahwa penguatan kapasitas pemerintah desa maupun pendamping desa menjadi hal yang diperlukan untuk mengurangi potensi terjadinya korupsi di desa. Penguatan ini penting dilakukan karena Tim menilai bahwa BUMDES di Desa Gendro ini memiliki potensi pengembangan. Selain potensi ekonomi desa, para pengelola juga berpotensi karena didominasi oleh generasi muda dengan kualitas SDM yang lebih baik dibanding pemerintah desa.

Berangkat dari analisis situasi tersebut di atas, program pengabdian kepada masyarakat ini dilakukan di bawah kerangka kajian ilmu komunikasi, khususnya dalam bidang komunikasi organisasi, dan ilmu administrasi terkait tata kelola keuangan. Program ini kelanjutan program sebelumnya yang berupa sosialisasi keterbukaan informasi public (Kriyantono et al., 2019). Secara khusus, program pengabdian kepada masyarakat ini ditujukan untuk (1) meningkatkan pengetahuan dan kapasitas komunikasi efektif dalam organisasi BUMDES, (2) meningkatkan pengetahuan bersama di antara pengelola BUMDES tentang dasar hukum dan tata kelola pelaporan keuangan BUMDES. Tercapainya kedua tujuan tersebut diharapkan dapat mewujudkan pengelolaan BUMDES secara profesional.

\section{METODE}

Untuk mencapai kedua tujuan dalam kegiatan pengabdian kepada masyarakat ini, terdapat empat tahap dan berlangsung pada Juli-September 2020. Tahap pertama, kegiatan dilakukan dalam bentuk penggalian data awal melalui wawancara secara informal dengan beberapa pengurus, yakni wawancara mendalam dengan suasana santai, sehingga diharapkan menghasilkan jawaban yang mendalam (Kriyantono, 2020b). Tujuan dari kegiatan ini adalah untuk memperoleh gambaran tentang permasalahan spesifik dari masing-masing pihak berkaitan dengan kendala utama yang dihadapi dalam pengelolaan BUMDES Podo Makmur. Tokoh kunci yang dilibatkan dalam wawancara secara terpisah ini adalah Kepala Desa Gendro, Sekretaris Desa Gendro, Ketua serta Bandahara BUMDES Podo Makmur. Di tahapan ini, tim memperoleh hasil yang berbeda antara keempat tokoh kunci tersebut dalam memandang permasalahan utama BUMDES Podo Makmur. Hal ini kemudian mendorong Tim Pengabdian kepada Masyarakat untuk melaksanakan tahapan kedua, yaitu analisis situasi partisipatif.

Tahap kedua ditujukan untuk memperoleh gambaran spesifik tentang permasalahan yang dihadapi bersama terkait pengelolaan BUMDES Podo Makmur. Analisis situasi partisipatif melibatkan sembilan pengurus dan pengawas BUMDES Podo Makmur Desa Gendro, Kabupaten Pasuruan, Jatim. Kegiatan ini dilaksanakan di Pendopo Balai Desa Gendro dengan menggunakan protokol kesehatan. Tahap kedua ini dilakukan melalui metode diskusi kelompok terfokus (FGD) untuk mendorong pengurus dan pengawas BUMDES Podo Makmur untuk bersama-sama menemukan berbagai permasalahan utama yang mereka hadapi sekaligus berbagai potensi yang mereka miliki. Tim pengabdian kepada masyarakat hanya berposisi sebagai fasilitator sehingga memungkinkan seluruh peserta dapat berdiskusi dari sudut pandang mereka masing-masing tanpa ada tekanan ataupun rasa tidak nyaman untuk mengutarakan pendapat karena keberadaan tim pengabdian kepada masyarakat. Melalui metode ini, tim memperoleh rumusan yang dipandang sebagai permasalahan utama sekaligus potensi yang dipahami secara bersama sebagai keunggulan yang mereka miliki dalam menjalankan Program BUMDES.

Hasil yang diperoleh pada tahap pertama dan kedua kemudian ditindaklanjuti dengan tahapan berikutnya (tahap ketiga) yang melibatkan metode workshop (pelatihan dan pembekalan) terkait dengan fungsi komunikasi dalam organisasi. Sebelum pelatihan dilaksanakan, dilakukan pengukuran untuk mengetahui loyalitas dan komitmen masingmasing peserta kegiatan terkait keterlibatannya dalam pengelolaan BUMDES Podo Makmur. Seperti halnya pada 
tahap pertama dan kedua, tahap ketiga ini melibatkan seluruh pengurus dan pengawas BUMDES Podo Makmur. Di samping itu, dilibatkan pula pendamping desa dan perwakilan perangkat desa mengingat pelatihan yang diberikan berkaitan dengan fungsi komunikasi dalam organisasi sehingga setelah mengikuti pelatihan ini peserta diharapkan mempunyai pengetahuan tambahan tentang komunikasi organisasi yang dilakukan secara efektif. Peningkatan pengetahuan tentang pentingnya komunikasi yang efektif dalam organisasi menjadi bekal bagi pengelolaan organisasi secara lebih professional sehingga pada akhirnya dapat memenuhi fungsi keterbukaan informasi publik sebagai dampak dari implementasi UU KIP.

Pada tahap keempat, dilaksanakan pembekalan dan pelatihan tentang dasar hukum pelaksanaan BUMDES serta pengelolaan keuangan BUMDES. Meskipun pelatihan ini secara khusus ditujukan untuk pengurus BUMDES Podo Makmur, satu para pengawas, dua perangkat desa serta satu pendamping desa tetap dilibatkan sehingga muncul pemahaman bersama tentang dasar hukum dan pengelolaan BUMDES Podo Makmur. Tim menjelaskan berbagai aturan tentang BUMDES serta tata cara pengelolaannya. Hal ini mengingat perbedaan cara pandang antara pendamping desa dan pengurus BUMDES tentang penggunaan dana BUMDES yang berkaitan dengan honorarium pelaksana menjadi salah satu kendala pengelolaan BUMDES Podo Makmur. Melalui pelatihan ini diharapkan dapat terbangun pemahaman bersama tentang teknis pengelolaan BUMDES sesuai dengan dasar hukum dan aturan dasar pengelolaan keuangan, sebagai dasar bagi pengelolaan organisasi secara professional. Secara teknis, kegiatan ini dilaksanakan di Pendopo Balai Desa Gendro dengan mengikuti protokol kesehatan, sebagaimana kedua kegiatan sebelumnya.

\section{HASIL DAN PEMBAHASAN}

\section{Hasil Pemetaan terhadap Permasalahan Mitra}

Sebagaimana telah dipaparkan sebelumnya, pemetaan terhadap permasalahan yang menyebabkan BUMDES Podo Makmur tidak berjalan secara produktif dilakukan melalui tahap pertama berupa wawancara mendalam secara terpisah pada pengurus dan perangkat desai yang berkaitan langsung dengan pengelolaan BUMDES Podo Makmur Desa Gendro, Kabupaten Pasuruan, jawa Timur. Berdasarkan proses tersebut, diperoleh hasil yang cukup berbeda antara pihak pengurus BUMDES dan pihak perangkat desa (Tabel 1).

Tabel 1. Identifikasi Permasalahan berdasarkan proses wawancara dan FGD

\begin{tabular}{|c|c|c|}
\hline No & $\begin{array}{l}\text { Poin Permasalahan } \\
\text { Berdasarkan sudut pandang Perangkat Desa }\end{array}$ & $\begin{array}{l}\text { Poin Permasalahan } \\
\text { berdasarkan sudut pandang Pengurus BUMDES }\end{array}$ \\
\hline 1 & $\begin{array}{l}\text { Belum ada laporan langsung tentang progress } \\
\text { pelaksanaan BUMDES. }\end{array}$ & $\begin{array}{l}\text { Rendahnya dukungan dan apresiasi Perangkat Desa. } \\
\text { BUMDES sudah berjalan namun masih minimal. }\end{array}$ \\
\hline 2 & Koordinasi antar pengurus minimal. & $\begin{array}{l}\text { Koordinasi antar pengurus rendah, pelaksanaan job } \\
\text { description tidak seimbang. }\end{array}$ \\
\hline 3 & $\begin{array}{l}\text { Tingginya tuntutan pengurus } \\
\text { namun kinerja belum ada. }\end{array}$ & $\begin{array}{l}\text { Sulitnya perangkat desa dalam memenuhi harapan pengurus } \\
\text { BUMDES. }\end{array}$ \\
\hline 4 & $\begin{array}{l}\text { Sudah dilakukan upaya komunikasi pada } \\
\text { pengurus BUMDES. }\end{array}$ & $\begin{array}{l}\text { Anggapan tidak adanya dukungan dan kepedulian dari } \\
\text { kades dan perangkat desa. }\end{array}$ \\
\hline
\end{tabular}

Berdasarkan temuan tersebut terlihat bahwa pada dasarnya kedua belah pihak menunjukkan kesamaan pandangan bahwa BUMDES Podo Makmur tidak dapat beroperasi secara produktif. Akan tetapi, kedua belah pihak menunjukkan perbedaan sudut pandang tentang akar penyebab terjadinya permasalahan tersebut. Di satu sisi, pengurus BUMDES menganggap tidak adanya dukungan dari perangkat desa menjadi salah satu penyebab pihak mereka enggan bekerja dengan optimal. Di sisi lainnya, perangkat desa menilai bahwa pengurus BUMDES terlalu banyak menuntut tanpa menunjukkan kinerja yang konkret.

Menindaklanjuti temuan tersebut, proses penggalian data untuk memetakan permasalahan kembali dilakukan dengan berfokus pada penggunaan analisis situasi secara partisipatif. Secara teknis, proses ini dilaksanakan pada tahap kedua dengan tim pengabdian kepada masyarakat bertindak sebagai fasilitator. Proses ini ditujukan untuk mendorong pengurus dan pengawas BUMDES Podo Makmur untuk bersama-sama menemukan berbagai permasalahan utama yang mereka hadapi sekaligus berbagai potensi yang mereka miliki. Tabel 2 menunjukkan hasil diskusi dan analisis bersama tentang permasalahan utama yang dihadapi serta potensi yang dimiliki pengelola BUMDES Podo Makmur. 
Tabel 2. Hasil analisis situasi secara partisipatif: Potensi dan masalah bersama dalam Pengelolaan BUMDES Podo Makmur

\begin{tabular}{ll}
\hline Hasil identifikasi permasalahan bersama & Hasil identifikasi terhadap potensi \\
\hline Organisasi belum berjalan sesuai tujuan awal & $\begin{array}{l}\text { SDM pengelola BUMDES yang masih muda, inovatif } \\
\text { dan dapat bekerja sama dengan baik }\end{array}$ \\
$\begin{array}{l}\text { Kurangnya dukungan dari desa } \\
\text { Kinerja tidak dapat optimal karena terbentur oleh } \\
\text { pekerjaan utama }\end{array}$ & $\begin{array}{l}\text { Potensi usaha yang besar baik dari sektor pariwisata } \\
\text { maupun sektor perdagangan dan peternakan }\end{array}$ \\
Tidak ada honor yang diterima dalam pengelolaan & \\
BUMDES Podo Makmur \\
$\begin{array}{l}\text { Kebingungan pada jenis usaha yang dipandang } \\
\text { menguntungkan }\end{array}$
\end{tabular}

Kegiatan analisis situasi secara partisipatif melalui FGD ini memungkinkan komunikasi dua arah timbal balik. Partisipan dapat menyampaikan aspirasi dengan sangat terbuka dan Tim pengabdian kepada Masyarakat lebih bertindak sebagai pendengar (Gambar 1).

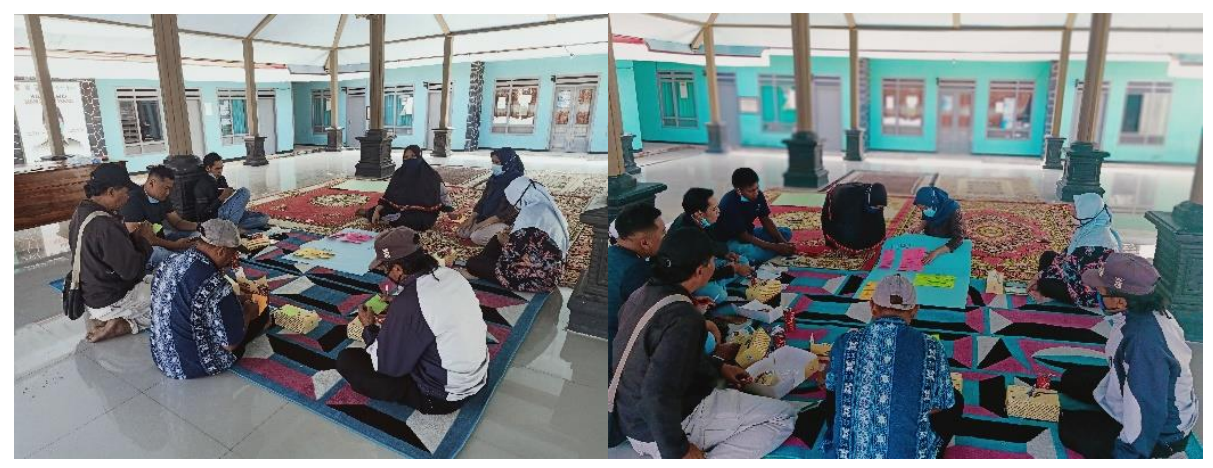

Gambar 1 Proses analisis situasi partisipatif

Berdasarkan tahapan kedua diketahui bahwa meskipun pengurus dan pengawas BUMDES Podo Makmur telah dapat menemukan permasalahan bersama dan menyadari potensi-potensi yang mereka miliki, pada kenyataannya tidak semua orang memahami tupoksinya di dalam pengelolalan BUMDES Podo Makmur. Secara spesifik, dalam proses diskusi bersama tim pengabdian kepada masyarakat, sebagian besar pengawas BUMDES Podo Makmur baru mengetahui bahwa mereka adalah pengawas dan selama ini belum pernah ikut berkontribusi dalam proses pengelolaan BUMDES dalam kapasitas mereka sebagai pengawas. Kondisi ini terjadi karena tidak ada komunikasi yang intensif antara perangkat desa serta pengurus BUMDES pada orang-orang yang bertanggung jawab sebagai pengawas BUMDES sejak hari pemilihan pengurus BUMDES di tahun 2018. Temuan ini kemudian menjadi dasar dilakukannya tahapan selanjutnya yaitu pelatihan tentang fungsi komunikasi dalam organisasi.

\section{Pelatihan Fungsi Komunikasi dalam Organisasi}

Tahapan ini dilakukan dengan melibatkan pengurus dan pengawas BUMDES, pendamping desa serta perangkat desa (Gambar 2). Meskipun menggunakan metode ceramah, dalam proses ini partisipan kegiatan dilibatkan secara aktif melalui berbagai dialog selama proses pelatihan dilakukan. Sebelum dan sesudah materi diberikan, dilakukan pengukuran untuk mengetahui sejauh mana efektivitas metode dapat dicapai. Sebelum proses pelatihan dilakukan, dilakukan pengukuran terhadap para partisipan khususnya pengurus dan pengawas BUMDES Podo Makmur untuk mengetahui bagaimana komitmen yang dimiliki terhadap organisasi BUMDES. Hal ini dilakukan sebagai tindak lanjut dari tahapan sebelumnya yang menemukan bahwa rendahnya kinerja pengurus dan anggota karena terbentur pekerjaan utama. Secara teknis, pengukuran dilakukan dengan mengadaptasi tiga komponen untuk mengukur komitmen pada organisasi sebagaimana dirumuskan Meyer et al. (1993) yang terdiri atas affective commitment, normative commitment, dan continuance commitment. Di samping itu, digunakan pula instrument penilaian komitmen pada organisasi dengan mengadaptasi model Walden et al. (2017). Berdasarkan hasil pengukuran (Tabel 3) dapat disimpulkan bahwa nilai rata-rata skor komitmen pengurus dan pengawas pada organisasi BUMDES Podo Makmur adalah sebesar $65.94 \%$. Hal ini berarti bahwa baik pengurus maupun pengawas tidak memiliki komitmen yang cukup tinggi pada organisasi BUMDES Podo Makmur.

Berdasarkan studi terdahulu, dikemukakan bahwa kepuasan kerja diprediksi menjadi salah satu faktor kunci bagi komitmen pada organisasi (Suryani, 2018). Sementara itu, kepuasan kerja dan peningkatan produktivitas kerja 
dipengaruhi kuat oleh komunikasi yang terjalin di antara anggota organisasi (Bedwell et al., 2014; Hargie, 2016), tetapi, dalam organisasi BUMDES Podo Makmur, ditemukan bahwa komunikasi tidak terjalin secara baik, secara kuantitas maupun kualitas antar pengurus BUMDES serta antara pengurus dan pengawas BUMDES. Hal ini turut berdampak pada produktivitas kerja dalam pengelolaan usaha BUMDES. Hal yang juga menjadi kendala adalah buruknya komunikasi yang terjalin antara perangkat desa dengan pengurus dan pengawas BUMDES Podo Makmur. Menurut para pengelola, perangkat desa terkesan acuh namun terus menuntut agar pengelola teknis BUMDES, khususnya pengurus dapat menunjukkan kinerja yang produktif dan memberikan pelaporan pada pernagkat desa untuk disampaikan pada masyarakat. Hal ini tidak hanya diungkapkan oleh pengurus BUMDES, tetapi juga oleh pendamping desa. Padahal komunikasi antara atasan dan bawahan dipandang turut berdampak pada peningkatan motivasi kerja (Shoraj \& Llaci, 2015). Dalam titik ini terlihat bahwa permasalahan komunikasi dalam organisasi BUMDES tidak hanya terjadi secara internal, tetapi juga secara eksternal yaitu dengan perangkat desa. Ironisnya, permasalahan ini seringkali tidak disadari mengingat anggota organisasi lebih banyak terfokus pada jenis usaha yang paling produktif untuk dijalankan dalam skema BUMDES.

Tabel 3. Hasil Pengukuran Komitmen Pengurus dan Pengawas pada Organisasi BUMDES Podo Makmur

\begin{tabular}{lllllllll}
\hline $\begin{array}{l}\text { Responden/ } \\
\text { Item }\end{array}$ & 1 & 2 & 3 & 4 & 5 & 6 & 7 & 8 \\
\hline 1 & 4 & 4 & 4 & 4 & 4 & 3 & 2 & 4 \\
2 & 4 & 2 & 2 & 2 & 4 & 2 & 2 & 2 \\
3 & 5 & 4 & 4 & 4 & 2 & 2 & 4 & 4 \\
4 & 4 & 4 & 4 & 4 & 4 & 5 & 2 & 4 \\
5 & 4 & 4 & 4 & 4 & 3 & 1 & 2 & 2 \\
6 & 4 & 4 & 5 & 4 & 3 & 2 & 2 & 4 \\
7 & 3 & 3 & 4 & 3 & 4 & 2 & 2 & 2 \\
8 & 3 & 4 & 4 & 4 & 4 & 2 & 2 & 4 \\
\hline Skor & 31 & 29 & 31 & 29 & 28 & 19 & 18 & 26 \\
\hline \multirow{2}{*}{ Rata - rata } & 26,375 & & & & & & \\
\hline
\end{tabular}

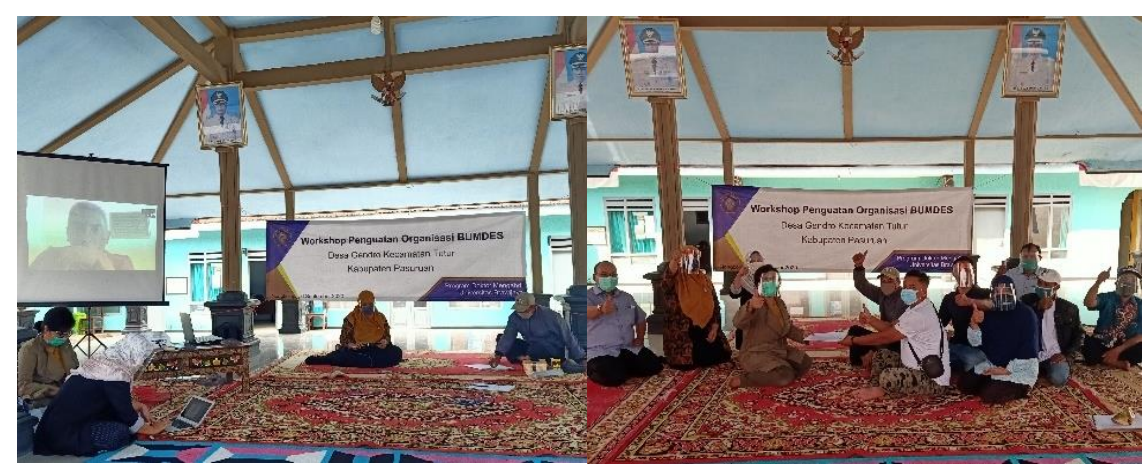

Gambar 2 Pelatihan tentang fungsi komunikasi dalam organisasi

Tabel 4. Hasil perhitungan pre-test dan post-test materi pentingnya komunikasi dalam organisasi

\begin{tabular}{llllll}
\hline \multicolumn{2}{l}{ Descriptive Statistics } & \multicolumn{5}{l}{} \\
\hline Pretest & 10 & Mean & Std. Deviation & Minimum & Maximum \\
\hline Posttest & 10 & 4,30 & 2,541 & 1 & 8 \\
\hline
\end{tabular}

Untuk menguraikan permasalahan tersebut, tim pengabdian kepada masyarakat memberikan pelatihan dengan materi tentang fungsi komunikasi dalam organisasi dengan tujuan meningkatkan kesadaran anggota organisasi bahwa untuk dapat menjalankan organisasi secara professional. Untuk itu, dibutuhkan komunikasi yang baik antar bagian dalam organisasi BUMDES. Berdasarkan Tabel 4, dapat diketahui bahwa rata-rata post-test lebih besar daripada pre- 
test. Untuk mengetahui apakah terdapat perbedaan antara hasil pre-test dan post-test dilakukan uji Wilcoxon, yang hasilnya dipaparkan di Tabel 5. Berdasarkan hasil dari perhitungan Wilcoxon Signed Rank Test, maka nilai Z yang didapat sebesar -2,209 dengan p value (Asymp. Sig 2 tailed) sebesar 0,027, yang berarti bahwa kurang dari batas kritis penelitian 0,05 sehingga dapat disimpulkan bahwa terdapat perbedaan bermakna antara sebelum dan sesudah pelatihan diberikan. Kegiatan pelatihan berjalan sangat komunikatif, penuh kekeluargaan, dengan aliran komunikasi dua arah timbal balik (Gambar 2).

Tabel 5. Wilcoxon Signed Ranks Test

\begin{tabular}{lllll}
\hline Ranks & & & \\
& & N & Mean Rank & Sum of Ranks \\
\hline Posttest - Pretest & Negative Ranks & 2a & 2,00 & 4,00 \\
& $\begin{array}{l}\text { Positive Ranks } \\
\text { Ties }\end{array}$ & $7 \mathrm{~b}$ & 5,86 & 41,00 \\
& Total & $1 \mathrm{c}$ & & \\
& $-2,209$ & & \\
\hline $\mathrm{Z}$ & 0,027 & & \\
P value Asym. Sig (2-tailed) & & & \\
\hline a. Posttest < Pretest & & & \\
b. Posttest > Pretest & & & \\
c. Posttest $=$ Pretest & &
\end{tabular}

\section{Pelatihan dan Pembekalan tentang Dasar Hukum Pelaksanaan BUMDES dan Pengelolaan Keuangan BUMDES}

Pelatihan ini merupakan tahapan terakhir dari kegiatan pengabdian kepada masyarakat yang dilakukan. Secara mendasar, tujuan dari dilaksanakannya pelatihan ini adalah meningkatkan pengetahuan seluruh pihak yang terlibat dalam pengelolaan BUMDES Podo Makmur berkaitan dengan dasar hukum dan teknis pelaporan keuangan. Hal ini tidak terlepas dari temuan permasalahan awal bahwa terdapat perbedaan pendapat serta kebingungan tentang alokasi dana untuk honorarium pengelola BUMDES. Berdasarkan paparan para pengurus BUMDES Podo Makmur, diketahui bahwa selama 2 tahun terakhir mereka hanya sekali mendapatkan honorium sebagai pengelola BUMDES, padahal di dalam Surat Keputusan Kepala Desa Gendro tentang pengurus BUMDES Podo Makmur tertulis bahwa honorarium pelaksana dapat diambil dari dana BUMDES. Akan tetapi, pendamping desa bersikukuh bahwa mengambil dana BUMDES untuk biaya gaji pengelola tidak boleh dilakukan.

Perbedaan pendapat ini yang kemudian membawa pada keputusan bahwa pengurus BUMDES Podo Makmur tidak memperoleh gaji dari pengelolaan BUMDES yang berupaya mereka jalankan. Keputusan ini semakin menurunkan motivasi kerja dari pengurus BUMDES terlebih sebagian besar pengurus BUMDES memiliki pekerjaan tetap yang lebih menjanjikan secara material. Sebagaimana ditegaskan Korir dan Kipkebut (2016) bahwa sistem pemberian reward finansial berpengaruh secara signifikan pada komitmen anggota pada organisasi. Berkaitan dengan kegiatan pengabdian kepada masyarakat, diberikan pelatihan dan pendampingan terkait konsep dasar dan fungsi aturan dalam pengelolaan BUMDES yang juga berdampak pada penyusunan laporan keuangan. Berbeda dengan pelatihan sebelumnya, materi ini disampaikan di bawah kerangka konsep ilmu administrasi untuk mendapatkan pengetahuan yang komprehensif tentang tata kelola organisasi di tingkat desa khususnya dalam pengelolaan BUMDES.

Tabel 6. Hasil Pengukuran Pre-test dan Post-test Pelatihan Dasar Hukum BUMDES dan Pelaporan Keuangan

\begin{tabular}{llllll}
\hline \multicolumn{2}{l}{ Descriptive Statistics } & \multicolumn{5}{l}{} \\
\hline & $\mathrm{N}$ & Mean & Std. Deviation & Minimum & Maximum \\
\hline Pretest & 10 & 5,60 & 1,350 & 3 & 7 \\
Posttest & 10 & 6,50 & 1,080 & 5 & 8 \\
\hline
\end{tabular}

Evaluasi dilakukan untuk mengukur pemahaman peserta tentang dasar hukum BUMDES. Berdasarkan Tabel 6 dapat diketahui bahwa rata-rata post-test lebih besar daripada pre-test. Untuk mengetahui apakah terdapat perbedaan secara signifikan antara hasil pre-test dan post-test dilakukan uji Wilcoxon (Tabel 7). Kemudian, tim melakukan uji signifikansi hasil. Hasil penghitungannya adalah signifikan. Artinya, dampak pengabdian masyarakat ini bersifat signifikan. 
Tabel 7. Wilcoxon Signed Ranks Test

\begin{tabular}{lllll}
\hline Ranks & & & & \\
\hline Posttest - Pretest & Negative Ranks & $1^{\text {a }}$ & Mean Rank & Sum of Ranks \\
& Positive Ranks & $7^{\mathrm{b}}$ & 4,00 & 3,00 \\
& Ties & $2^{\mathrm{c}}$ & & 33,00 \\
& Total & 10 & & \\
Z & $-2,165$ & & & \\
Asymp. Sig. (2-tailed) & 0,030 & & & \\
\hline
\end{tabular}

a. Posttest < Pretest

b. Posttest $>$ Pretest

c. Posttest $=$ Pretest

Berdasarkan hasil dari perhitungan Wilcoxon Signed Rank Test, maka nilai Z yang didapat sebesar -2,165 dengan $\mathrm{p}$ value (Asymp. Sig 2 tailed) sebesar 0,030. P value ini kurang dari batas kritis penelitian 0,05 sehingga dapat disimpulkan bahwa terdapat perbedaan signifikan bermakna antara sebelum dan sesudah pelatihan diberikan. Dengan demikian, pelatihan tentang tata kelola keuangan ini telah memberikan dampak yang signifikan bagi para peserta dalam meningkatkan kapasitas pengelolaan BUMDES. Hasil ini makin mempertegas, perlunya workshop atau pelatihan dalam berbagai kegiatan pengabdian masyarakat. Beberapa pprogram pengabdian kepada masyarakat, seperti Pratiwi et al. (2020) dan Zubair et al. (2019) sudah membuktikan pelatihan bisa meningkatkan kemampuan kognisi masyarakat.

\section{KESIMPULAN}

Kegiatan Pengabdian kepada Masyarakat telah berhasil meningkatkan pengetahuan pengurus dan pengawas, melalui kapasitas komunikasi dan transparansi tata kelola keuangan, di BUMDES Podo Makmur dan pendamping Desa Gendro. Di samping itu, pelatihan yang diberikan juga telah berhasil meningkatkan pengetahuan bersama di antara pengelola BUMDES tentang dasar hukum dan teknis pelaporan BUMDES. Tim pengabdian kepada masyarakat menyadari bahwa untuk mencapai profesionalitas dalam pengelolaan BUMDES tidak hanya bergantung pada aspek komunikasi semata, sehingga tim pengabdian kepada masyarakat merekomendasikan bahwa diperlukan pendampingan lebih jauh terhadap pihak pengelola BUMDES baik dengan mendalami budaya yang berlaku di dalam organisasi BUMDES maupun gaya kepemimpinan yang sesuai di dalam organisasi non-profit. Di masa depan, perlu dilakukan penguatan tata kelola komunikasi dan transparansi dengan menggunakan website sebagai bagian perkembangan masyarakat.

\section{UCAPAN TERIMA KASIH}

Ucapan terima ksih disampaikan kepada Universitas Brawijaya yang telah memberikan dana hibah Doktor Mengabdi sehigga Program Pengabdian kepada Masyarakat beserta publikasi ini dapat dilaksanakan.

\section{DAFTAR PUSTAKA}

Anwar, M. S. (2020, Juli 20). Khofifah minta pengelolaan BUMDes di Jatim profesional. Klik Jatim. https://klikjatim.com/khofifah-minta-pengelolaan-bumdes-di-jatim-profesional/

Batubara, P. (2017, Oktober 16). Kasus suap WTP Kemendes, 2 auditor BPK diadili di pengadilan tipikor. Oke News. https://nasional.okezone.com/read/2017/10/16/337/1796128/kasus-suap-wtp-kemendes-2-auditor-bpk-diadilidi-pengadilan-tipikor

Bedwell, W. L., Salas, E., Funke, G. J., \& Knott, B. A. (2014). Team workload: A multilevel perspective. Organizational Psychology Review, 4(2), 99-123. https://doi.org/10.1177/2041386613502665

Bunga, M., Aswari, A., \& Djanggih, H. (2018). Konsepsi penyelamatan dana desa dari perbuatan korupsi. Halu Oleo Law Review, 2(2), 448-459.

Charoensukmongkol, P., \& Moqbel, M. (2014). Does Investment in ICT curb or create more corruption? A crosscountry analysis. Public Organization Review, 14(1), 51-63. https://doi.org/10.1007/s11115-012-0205-8 
Estrada, L., \& Bastida, F. (2020). Effective transparency and institutional trust in Honduran Municipal Governments. Administration \& Society, 52(6), 890-926. https://doi.org/10.1177/0095399719874346

Febriananingsih, N. (2012). Keterbukaan informasi publik dalam pemerintahan terbuka menuju tata pemerintahan yang baik. Jurnal Rechts Vinding: Media Pembinaan Hukum Nasional, 1(1), 135-156. https://doi.org/10.33331/rechtsvinding.v1i1.110

Hargie, O. (2016). The importance of communication for organisational effectiveness. In F. Lobo (Ed.), Psicologia do Trabalho e das Organizações (hal. 15-32). Axioma.

Hawes, J. O., Rawlins, B., \& Plowman, K. D. (2015). Transparency and city government communications. Public Relations Journal, 9(3), 1-16.

Herdiana, D. (2019). Kecenderungan perilaku koruptif kepala desa dalam pembangunan desa. Matra Pembaruan: Jurnal Inovasi Kebijakan, 3(1), 1-11. https://doi.org/10.21787/mp.3.1.2019.1-11

Jatiningrum, C., Fauzi, Irviani, R., Mujiyati, \& Hasan, S. (2020). An investigation on the effect of audit committee on financial reporting quality in pre and post IFRS adoption: Evidence from Malaysian companies. Humanities and Social Sciences Reviews, 8(2), 25-35. https://doi.org/10.18510/hssr.2020.824

Kadir, Y., \& Moonti, R. M. (2018). Pencegahan korupsi dalam pengelolaan dana desa. Jurnal IUS Kajian Hukum dan Keadilan, 6(3), 430-442. https://doi.org/10.29303/ius.v6i3.583

Korir, I., \& Kipkebut, D. (2016). The effect of reward management on employees commitment in the universities in Nakuru County-Kenya. Journal of Human Resource Management, 4(4), 37-48. https://doi.org/10.11648/j.jhrm.20160404.12

Kriyantono, R. (2015). Konstruksi humas dalam tata kelola komunikasi lembaga pendidikan tinggi di era keterbukaan informasi publik. Jurnal Pekommas, 18(2), 117-126.

Kriyantono, R. (2016). Public Relations writing. Teknik produksi media public relations dan publisitas korporat. Prenada.

Kriyantono, R. (2019a). Apologia strategies and ethical aspects of government public relations in a crisis situation. Jurnal Representamen, 5(02), 32-41. https://doi.org/10.30996/REPRESENTAMEN.V5I02.2937

Kriyantono, R. (2019b). Public relations activities of state universities based on excellence theory. Avant Garde: Jurnal Ilmu Komunikasi, 7(2), 170. https://doi.org/10.36080/ag.v7i2.901

Kriyantono, R. (2020a). Efektivitas website perguruan tinggi negeri sebagai penyedia informasi bagi mahasiswa. Jurnal Studi Komunikasi, 4(1), 117-142. https://doi.org/10.25139/jsk.v4i1.1799

Kriyantono, R. (2020b). Teknik praktis riset komunikasi kuantitatif dan kualitatif. Prenada.

Kriyantono, R., Destrity, N. A., Amrullah, A. A., \& Rakhmawati, F. Y. (2017). Management of public relations for supporting the anti-corruption national program in Indonesia. International Journal of Applied Business and Economic Research, 15(20), 293-303.

Kriyantono, R., Laturrakhmi, Y. F., Swastikawara, S., Illahi, A. K., \& Ari, D. P. S. (2019). pemberdayaan perangkat desa dalam penyampaian informasi publik untuk mencegah korupsi dalam pelaksanaan program bumdes di DESA Gendro - Kabupaten Pasuruan. Abdimas: Jurnal Pengabdian Masyarakat Universitas Merdeka Malang, 4(2), 23-30. https://doi.org/10.26905/abdimas.v4i2.3229

Kurnia, T. (2019, April 5). Wawancara Khusus Mendes PDTT: Warga miskin di desa bakal lebih sedikit dibanding kota. Liputan 6. https://www.liputan6.com/bisnis/read/3931763/wawancara-khusus-mendes-pdtt-wargamiskin-di-desa-bakal-lebih-sedikit-dibanding-kota

Lawal, A. I., Oseni, E., Babajide, A. A., Lawal-Adedoyin, B., \& Bonetipin, F. (2020). The impact of international financial reporting standard (IFRS) adoption on key financial ratios in Nigeria. Humanities and Social Sciences Reviews, 8(4), 289-300. https://doi.org/10.18510/hssr.2020.8430

Mashabi, S. (2020, Januari 23). Indeks persepsi korupsi Indonesia pada 2019 naik jadi 40. Kompas. https://nasional.kompas.com/read/2020/01/23/16565951/indeks-persepsi-korupsi-indonesia-pada-2019-naikjadi-40?page=all

Meyer, J. P., Allen, N. J., \& Smith, C. A. (1993). Commitment to organizations and occupations: extension and test of a three-component conceptualization. Journal of Applied Psychology, 78(4), 538-551. https://doi.org/10.1037/0021-9010.78.4.538

Pina, V., Torres, L., \& Royo, S. (2010). Is e-government promoting convergence towards more accountable local 
governments? International Public Management Journal, 13(4), 350-380. https://doi.org/10.1080/10967494.2010.524834

Pratiwi, D., Santoso, G. B., Mardianto, I., Sediyono, A., \& Rochman, A. (2020). Pengelolaan Pengelolaan Konten Web Menggunakan Wordpress, Canva dan Photoshop untuk Guru-Guru Wilayah Jakarta. Abdihaz: Jurnal Ilmiah Pengabdian pada Masyarakat, 2(1), 11-15. https://doi.org/10.32663/abdihaz.v2i1.1093

Rahman, F. (2011). Korupsi di tingkat desa. Governance: Jurnal Ilmu Pemerintahan, 2(1), 13-24.

Retnowati, E. (2012). Keterbukaan informasi publik dan good governance (antara das sein dan das sollen). Perspektif, 17(1), 54-61. https://doi.org/10.30742/perspektif.v17i1.94

Shoraj, D., \& Llaci, S. (2015). Motivation and its impact on organizational effectiveness in Albanian businesses. SAGE Open, 5(2), 1-8. https://doi.org/10.1177/2158244015582229

Suryani, I. (2018). Factors affecting organizational commitment. Jurnal Manajemen dan Inovasi, 9(1), $26-34$. https://doi.org/10.24815/JMI.V9I1.11418

Tempo. (2019, Maret 6). Mendes Eko Putro: Prioritas dana desa 2019 untuk pemberdayaan ekonomi desa. Tempo. https://bisnis.tempo.co/read/1182512/mendes-eko-putro-prioritas-dana-desa-2019-untuk-pemberdayaanekonomi-desa/full\&view=ok

Walden, J., Jung, E. H., \& Westerman, C. Y. K. (2017). Employee communication, job engagement, and organizational commitment: A study of members of the Millennial Generation. Journal of Public Relations Research, 29(2-3), 73-89. https://doi.org/10.1080/1062726X.2017.1329737

Zubair, F., Bakti, I., \& Yustikasari, Y. (2019). Pemberdayaan Perangkat Desa Terampil Bermedia dalam Membangun Kesadaran dan Kepedulian Masyarakat terhadap Lingkungan di Desa Cikeruh Kecamatan Jatinangor Kabupaten Sumedang. Abdihaz: Jurnal Ilmiah Pengabdian pada Masyarakat, 1(2), 66-73. https://doi.org/10.32663/abdihaz.v1i2.955 